\title{
The Abstract: The letter of presentation for a scientific paper
}

\author{
Diego CAMPS, MD*
}

\section{SUMMARY}

The abstract is a part of scientific articles placed at the beginning of such. It guides us quickly and accurately about the information we will find in the complete manuscript. It must be written by selecting the appropriate words and sentences to achieve consistent, clear, and concise contents. We can group the abstract into two types according to their content: the descriptive abstract, which guides the reader regarding the contents of the article but requires reading the full text for further details; and the informative abstract, which condenses the study and provides accurate data about the contents of the paper. The abstract has become a fundamental part of the scientific article, especially with the explosive growth of information; an adequate and well-built abstract allows scientists and researchers to recognize the work done by its authors. Attention should be dedicated to its construction because the success of our publication depends upon the very abstract.

\section{Keywords: Summary; Scientific writing; Mistakes; Health; Publication components.}

\section{El resumen: la carta de presentación de un trabajo científico}

\section{RESUMEN}

El resumen es un segmento del artículo científico que se ubica al inicio del mismo, y nos orienta en forma rápida y precisa sobre la información que encontraremos en el manuscrito completo. Debe ser escrito seleccionando adecuadamente las palabras y oraciones, para lograr un contenido coherente, claro y conciso. Podemos agrupar a los resúmenes en dos de acuerdo con su contenido: los descriptivos, que orientan al lector sobre el contenido del artículo y hacen necesaria una lectura del manuscrito para conocer detalles; y los informativos, que condensan el estudio pero brindan datos precisos sobre su contenido. El resumen se ha convertido en una pieza fundamental en un artículo, sobre todo con la creciente explosión de la información; además un resumen adecuado y bien construido permite que los científicos e investigadores reconozcan la labor realizada por sus autores. Debemos prestar mucha atención a su elaboración porque de él depende el éxito de nuestra publicación.

Palabras clave: Resumen; Redacción científica; Errores; Salud; Componentes de publicaciones.

The abstract is a segment of the scientific article placed at the beginning of such and which rapidly and precisely guides us on the nature of the information we will find in the complete manuscript ${ }^{1}$.

According to the International Council of Medical Journal Editors, ICMJE2 ${ }^{2}$, the abstract should provide the context and purpose of the study, the basic procedures, the most important results, and its main conclusions; furthermore, it should highlight the novel and important aspects arising from the work.
We may group abstracts into two types, according to their content: descriptive and informative abstracts. Both differ in their writing and by what they contribute to readers.

Descriptive abstracts. These describe the core theme and purpose of the research, providing data on methods used although not always showing the relevance of the work and the conclusions. Occasionally, these only present the organization of the work. Descriptive abstracts (or indicative per English language literature)

\footnotetext{
* Adjunct Professor, Biochemistry and Biophysics, School of Odontology, Faculty of Medicine, Universidad Católica de Córdoba, Argentina. Director, Departamento de Información Científica y Técnica, Faculty of Medicine, Universidad Católica de Córdoba, Argentina. Executive Editor, International Archives of Medicine, USA.

Received for publication July 23, 2009 Accepted for publication January 12th, 2010
} 
bear the advantage of using 100 to 150 words; some journals use this format to save space.

These abstracts are inconvenient in that, by not including a detailed presentation of the results, it is necessary to have access to the complete article to learn of such; they may present the results via a phrase synthesizing them, without contributing numerical or statistical data. Ultimately, these guide readers on the nature of the contents of the article, but it is necessary to read the whole manuscript to know further details.

Informative abstracts. Informative abstracts appear in two thirds of the articles published in biomedical journals ${ }^{3}$. These abstracts answer the questions: what, how, and why was the work done, what was found, and is the significance of the finding. These abstracts condense the study in less than 250 words, providing accurate data on the contents of the work, especially on the results section. Informative abstracts are short scientific productions, since they follow the IMRaD structure $^{3}$ and can in fact replace the whole text, because readers extract from these the most valuable information and in many instances it is not necessary to read the complete text.

Recommendations by the CONSORT ${ }^{4}$ declaration, in its adaptation for abstracts, offer a guide for the elaboration of an abstract of a clinical trial in structured and informative manner, using up to 400 words and briefly including the Title, Methods (participants, interventions, objective, outcomes, randomization, blind tests), Results (number of randomizations, recruitment, number of analyses, outcome, important adverse effects), and Conclusions, registry of the clinical trial and conflict of interests.

Structural design of the abstract. A structured abstract has a paragraph for each section: Introduction, Materials and Methods, Results, and Conclusion (it may even include paragraphs for the objectives or other sections). This type of presentation is often required for informative abstracts. The CONSORT ${ }^{4}$ declaration suggests the presentation of clinical trials with structured abstracts, as has already been mentioned.

The origin of structured abstracts dates to 1987 , when the Ad Hoc Working Group proposed the use of more informative abstracts ${ }^{3}$. They proposed a length of 250 words, written in narrative form and with sentences separated in eight parts (divided new paragraph): objective, design, setting, patients or participants, interventions, main finding, results and conclusions. It was denominated as structured abstract in the editorial of that particular number ${ }^{3}$, which is why they are currently considered synonymous, although they may not be: structuring an abstract permits its informative development.

A semi-structured abstract is written in only one paragraph, where each sentence corresponds to a section. All the sections of the article are present as in the structured abstract.

When the abstract does not present divisions between each section, and it may not even present any of them, it is a non-structured abstract. The sentences are included in a sole paragraph. This type of presentation is ideal for descriptive abstracts.

Errors in the creation of an abstract. As its name indicates, the abstract of an article should contribute to readers the most relevant aspects of each part of the whole manuscript, maintaining a balance between excessive detail and a vague contribution of information. This allows readers to determine the relevance of its contents for their interests and decide if they should proceed with reading the whole article 5 .

The abstract should be written by adequately selecting the words and sentences to accomplish coherent, clear, and concise contents. A common defect is including adequate information like abbreviations, excessive acronyms, bibliographic references, or figures ${ }^{1,6}$. The length of an abstract will be determined by the instructions to authors furnished by each journal; and we may consider that an excessively lengthy abstract is the most frequent error.

In writing the abstract, we should bear in mind that the sections should maintain coherence and order and that the conclusions must be substantiated by the results revealed and respond to the objectives proposed. Frequently, abstracts have poorly defined objectives, excessive numerical data and statistical results, and conclusions not based on results presented.

Comments. It is worth noting that informative abstracts represent the latest evolution or change marked in scientific articles. Its introduction is recent and there is consensus to propagate its use $\mathrm{e}^{7}$, but each journal dictates its own details, requiring authors to follow them prior to any submission and comply with the instructions for authors by each journal ${ }^{2}$.

In a scientific article, the abstract has become a 
fundamental piece, above all with the explosive growth of information and with the need of professionals to keep up to date ${ }^{8}$. Scientists seeking relevant information for their research, as well as health professionals who need to know the latest advancements in research have to read numerous scientific articles per day ${ }^{9}$. However, they only select those they consider relevant or most attractive. This section is based, fundamentally, in reading the abstract, which is why herein we bestow great importance to the abstract because it can be decisive in whether our article will or will not be read.

The growth of science and the birth of a science of science, has given rise to bibliometric research that is nourished from bibliographic data bases, where, stemming from abstracts of articles, relevant data are obtained as indicators of scientific productivity ${ }^{10}$.

Also, we are part of an era in which the capacity of researchers is measured by the impact of their publications, although discrepancies on this issue may exist $^{10}$. It is thus that an adequate and well-constructed abstract permits scientists and researchers to become aware of the work done by its authors.

A good abstract sometimes guarantees that we will read a good article, but a bad abstract is always a guarantee that an undesirable article will follow. We must pay close attention to its elaboration, because the success of our publication depends on it.

\section{REFERENCIAS}

1. Budgell BS. Writing a biomedical research paper. New York: Springer; 2009.

2. Uniform Requirements for Manuscripts Submitted to Biomedical Journals. Writing and editing for biomedical publication. [fecha de acceso 19 de abril de 2009]. URL disponible en: http://www.icmje.org

3. Nakayama T, Hirai N, Yamaraki S, Naito M. Adoption of strutured abstracts by general medical journals and format of structured abstract. J MedLib Assoc. 2001; 93: 237-42.

4. Hopewell S, Clarke M, Moher D, Wager E, Middleton P, Altman DG, Schulz KF and the CONSORT Group. CONSORT for reporting randomised trials in journal and conference abstracts. Lancet. 2008; 371:281-3.

5. Llanos G, Reyes CA. La alegría de publicar 4. Los cien pecados de la presentación de artículos científicos.Colomb Med.2002; 33: $138-40$.

6. Day R. Como escribir y publicar trabajos científicos. $3^{\mathrm{a}} \mathrm{ed}$. Washington: OPS; 2005.

7. Guimaraes CA. Structured abstracts: narrative review.ActaCir Bras. 2006; 21:263-8.

8. Camps D. El artículo científico: Desde los inicios de la escritura hasta el IMRyD. Arch Med. 2007; 3. [fecha de acceso 18 de Abril de 2009]. Disponible en URL: www.intarchmed.com

9. Glasziou P, Del Mar C, Salisbury J.Evidence-basedmedicine workbook. London: BMJ Publishing Group; 2003.

10. Camps D. Limitaciones de los indicadores bibliométricos en la evaluación de la actividad científica biomédica. ColombMed. 2008; 39: 74-9. 